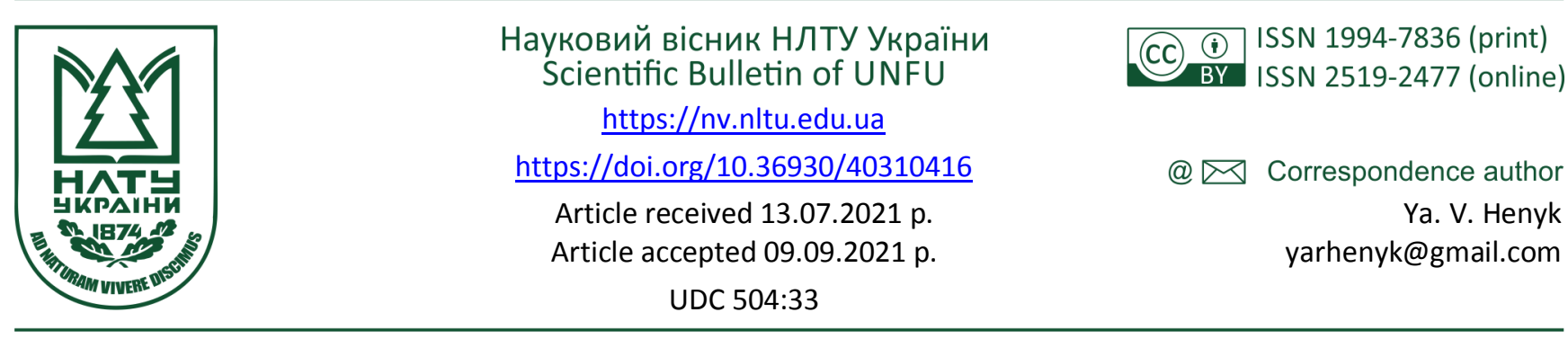

О. В. Геник ${ }^{1}$ М. П. Мельникович ${ }^{2}$, Я. В. Геник ${ }^{1}$

${ }^{1}$ Національний лісотехнічний університет Украӥни, м. Львів, Украӥна

${ }^{2}$ Інституту лісу, снігу і ландшафту (WSL), Швейцарія

\title{
ДОСТУПНІСТЬ ЛІСОВИХ РЕСУРСІВ ДЛЯ МАЛОГО БІЗНЕСУ ТА ЗАПОБІГАННЯ ВИКОРИСТАННЮ ДЕРЕВИНИ НЕЗАКОННОГО ПОХОДЖЕННЯ В КАРПАТСЬКОМУ РЕГІОНІ УКРАЇНИ
}

\begin{abstract}
Наведено результати досліджень доступності деревини та інших лісових ресурсів для малого бізнесу, основних загроз лісовим екосистемам Карпатського регіону країни та дієвих заходів із запобігання використанню деревини незаконного походження в підприємницькій діяльності. Оцінено стан лісових екосистем Карпат мешканцями місцевих територіальних громад - лідерами громадської думки, фахівцями лісового господарства, представниками органів місцевого самоврядування та малого бізнесу. Встановлено частку обізнаності мешканців гірських регіонів 3 екологічними проблемами своєї місцевості, 3 чинним законодавством у сфері ведення лісового господарства в Україні та 3 правовим регулюванням у цій же сфері у країнах Європейського Союзу. Здійснено аналіз основних загроз лісовим екосистемам та встановлено найвагоміші 3 них - недосконала законодавча база, корупційні схеми заготівлі деревини; самовільне вирубування лісів місцевими жителями та низька екологічна культура мешканців. Визначено основні чинники, що найбільше спонукають до використання деревини незаконного походження в малому бізнесі (різниця в цінах на деревину законного та незаконного походження, достатньо простий спосіб отримання деревини, наявність тіньового сектору в економіці та відсутність ефективних штрафних санкцій), а також заходи, що сприяють усуненню використання деревини незаконного походження в підприємницькій діяльності (припинення нелегального експорту переробленої деревини, посилення митного контролю, покращення роботи правоохоронних органів і сертифікація походження деревини). Встановлено невідкладні заходи, що сприяють забезпеченню прав малого бізнесу на використання деревини та інших лісових ресурсів, зокрема: налагодження партнерських стосунків між бізнесменами, громадою та владними структурами; забезпечення прозорості механізму прийняття рішень владними структурами; відкритість і доступність інформації про проблеми лісового господарства. Визначено, що найважливішим у забезпеченні доступності малого бізнесу до лісових ресурсів є зменшення кількості дозвільних процедур і документів та зменшення тиску владних і політичних структур на малий бізнес та ведення підприємницької діяльності.
\end{abstract}

Ключові слова: лісові екосистеми; доступ до лісових ресурсів; деревина незаконного походження; підприємницька діяльність; мешканці гірських громад.

\section{Вступ / Introduction}

Лісові насадження Карпатського регіону України за своїм призначенням виконують не тільки середовищетвірні, рекреаційно-оздоровчі та природно захисні функції, але і відіграють вагому роль у забезпеченні потреб як місцевого населення, так і країни загалом, у лісових pecypcax $[4,6,16]$. Для мешканців гірського регіону країни лісові екосистеми $є$ не тільки джерелом отримання деревини для господарських потреб і місцем збирання ягід, грибів і лікарської сировини, але і ресурсом для ведення підприємницької діяльності та розвитку малого бізнесу [2, 10, 14].

Соціальний та економічний розвиток об'єднаних територіальних громад у Карпатському регіоні України значною мірою характеризує рівень розвитку підприємництва та малого бізнесу, пов'язаного із лісовими екосистемами та лісовими ресурсами, а сталість розвитку гірського регіону залежить насамперед від екосистемних і рекреаційних послуг лісових насаджень. Зважаючи на важливість лісових екосистем для гірських об'єднаних територіальних громад, надзвичайно актуальними постають питання щодо доступності малого бізнесу до лісових ресурсів та запобігання використанню деревини незаконного походження у підприємницькій діяльності.

Об'єкт дослідження - доступність лісових ресурсів для підприємницької діяльності та використання деревини лісозалежними громадами Карпатського регіону країни в малому бізнесі.

\section{Інформація про авторів:}

Геник Оксана Володимирівна, канд. екон. наук, доцент, кафедра економіки підприємства. Email: yarhenyk@gmail.com; https://orcid.org/0000-0003-3887-0581

Мельникович Мар'яна Петрівна, канд. екон. наук, наук. співробітник. Email: yarhenyk@gmail.com

Геник Ярослав Вячеславович, д-р с.-г. наук, доцент, завідувач кафедри ландшафтної архітектури, садово-паркового господарства та урбоекологіï. Email: yarhenyk@gmail.com; https://orcid.org/0000-0002-6079-6827

Цитування за Дсту: Геник О. В., Мельникович М. П., Геник Я. В. Доступність лісових ресурсів для малого бізнесу та запобігання використанню деревини незаконного походження в Карпатському регіоні України. Науковий вісник НлТУ України. 2021, т. 31, № 4. C. 98-103.

Citation APA: Henyk, O. V., Melnykovych, M. P., \& Henyk, Ya. V. (2021). Availability of forest resources to small-scale business and prevention of the use of illegal timber in the Carpathian region of Ukraine. Scientific Bulletin of UNFU, 31(4), 98-103. https://doi.org/10.36930/40310416 
Предмет дослідження - процеси законного доступу до отримання деревини для ведення малого бізнесу та запобігання використанню деревини незаконного походження у підприємницькій діяльності.

Мета роботи - встановлення можливостей отримання деревини для ведення підприємницької діяльності та визначення невідкладних заходів зі сприяння забезпеченню прав малого бізнесу на використання лісових ресурсів.

Для досягнення зазначеної мети визначено такі основні завдання дослідження: оцінити стан лісів мешканцями гірських громад; встановити вагомі загрози лісовим екосистемам Карпатського регіону країни; визначити основні чинники, що спонукають до використання деревини незаконного походження в малому бізнесі; встановити заходи, що сприяють усуненню використання деревини незаконного походження у підприємницькій діяльності та визначити заходи із забезпечення прав малого бізнесу на використання лісових ресурсів.

Наукова новизна отриманих результатів досліджен$н я$ - оцінено шляхи доступності лісових ресурсів для малого бізнесу та встановлено невідкладні заходи із запобігання використанню деревини незаконного походження у підприємницькій діяльності.

Практична значущість результатів дослідження можливе подальше визначення шляхів ефективного забезпечення доступу малого бізнесу до деревини та інших лісових ресурсів, а також розроблення дієвих заходів із запобігання використанню деревини та продуктів перероблення лісу незаконного походження у підприємницькій діяльності.

Аналіз останніх досліджсень та публікацій. Найбільшим багатством Карпатського регіону України є лісові екосистеми, а лісове господарство та лісова галузь відіграють вагому роль у забезпеченні добробуту місцевого населення та сталого розвитку об'єднаних територіальних громад $[7,8,9,12,15]$. Проблеми із забезпечення збалансованого розвитку гірських територій Карпатського регіону країни, визначення шляхів сталого лісокористування та використання лісових ресурсів місцевим населенням у підприємницькій діяльності досліджували науковці Національного лісотехнічного університету України, Інституту екології Карпат НАН України, Українського науково-дослідного інституту гірського лісівництва ім. П. С. Пастернака, Львівського національного університету ім. Івана Франка, Прикарпатського національного університету ім. Василя Стефаника, Ужгородського національного університету та інших науково-дослідних і освітніх установ [2, 3, 10, 14].

Питання сталого лісокористування, еколого-економічних засад ведення лісового господарства, раціонального використання лісових ресурсів і відновлення лісових екосистем в Карпатському регіоні України порушено в численних наукових роботах С. А. Генсірука, М. А. Голубця, С. М. Стойка, Г. Т. Криницького, М. В. Чернявського, В. І. Парпана, І. Ф. Калуцького, В. Д. Солодкого, І. М. Синякевича, А. М. Дейнеки, І. П. Соловія та низки інших науковців $[4,5,6,12,13,16]$.

Незважаючи на вагомість i значущість наукових напрацювань із питань сталого лісокористування та раціонального використання лісових екосистем, дослідження аспектів доступу місцевого населення та малого бізнесу до лісових ресурсів і надалі є актуальними та потребують нових наукових і практичних доробок для вирішення еколого-економічних та соціальних проблем мешканців гірських регіонів та об'єднаних територіальних громад $[1,11]$.

Матеріали та методи дослідження. Дослідження щодо обмежень у доступі малого бізнесу до лісових ресурсів у Карпатському регіоні Україні здійснено в межах програми ENPI-FLEG "Удосконалення систем правозастосування й управління в лісовому секторі у країнах-учасницях Європейської політики добросусідства" та в розрізі науково-дослідних тематик НЛТУ України, зокрема "Формування економічного механізму забезпечення суспільства послугами екосистем як підгрунтя трансформації галузевої політики і менеджменту у лісовому господарстві".

Дослідження доступності малого бізнесу до лісових ресурсів та забезпечення прав підприємців на використання деревини, а також важливості заходів із запобігання використанню деревини незаконного походження в бізнесі здійснено методом анкетного стандартного опитування "обличчям до обличчя" представників місцевих громад територій Хустського району Закарпатської області, Косівського району і Яремчанської міської ради Івано-Франківської області та Сколівського і Старосамбірського районів Львівської області. Для територій проведення досліджень характерна значна лісистість, а лісова галузь відіграє вагому роль в економіці району.

Експертами виступали мешканці громад (представники органів місцевого самоврядування, малого бізнесу та фахівці лісового господарства), які дуже добре обізнані із станом справ у лісовій галузі регіону та $є$ лідерами громадської думки.

Загалом опитано 450 респондентів - по 150 на територіях адміністративних районів Закарпатської, ІваноФранківської та Львівської областей, що дає змогу достовірно і реалістично оцінити доступність малого бізнесу до лісових ресурсів та встановити невідкладні заходи iз запобігання використанню деревини незаконного походження у підприємницькій діяльності.

Методики опрацювання результатів досліджень базувались на апробованих методологічних підходах та відповідають основним вимогам формування емпіричної бази наукових досліджень соціологічними методами. Опрацювання та аналіз отриманих результатів досліджень виконували спеціалізованим програмним забезпечення SPSS $[1,11]$.

\section{Результати досліджень та їх обговорення / Research results and their discussion}

Проаналізувавши результати досліджень у громадах гірських регіонів, з'ясовано, що більшість місцевого населення стан лісових екосистем загалом оцінює як "радше поганий, ніж добрий" - 40,9 \% опитаних респондентів. Значна частина мешканців також вважає, що стан лісових насаджень у їхній місцевості $є$ "добрий" $32,2 \%$. Натомість 15,1\% мешканців гірських громад вважає, що загальний стан лісів на території їх проживання є "поганий" (табл. 1).

Загалом думки лідерів територіальних громад i представників малого бізнесу та фахівців лісового господарства дещо різняться. Так, за отриманими результатами досліджень більшість спеціалістів лісового господарства стан лісів своєї місцевості оцінюють як "добрий" i "дуже добрий" - 53,3 \%, натомість більшість лідерів громадської думки та підприємців стан лісів у 
своєму регіоні вважають радше поганим, ніж добрим відповідно 41,4 та 48,0 \% респондентів.

Табл. 1. Оцінка стану лісів мешканцями гірських громад / Assessment of forest condition by residents of mountain communities

\begin{tabular}{|l|c|c|c|c|c|}
\hline \multicolumn{1}{|c|}{ Мешканці громад } & $\begin{array}{c}\text { Важко } \\
\text { відпо- } \\
\text { вісти }\end{array}$ & $\begin{array}{c}\text { Пога- } \\
\text { ний }\end{array}$ & $\begin{array}{c}\text { Радше } \\
\text { ніж доний- } \\
\text { рий }\end{array}$ & $\begin{array}{c}\text { Доб- } \\
\text { рий }\end{array}$ & $\begin{array}{c}\text { Дуже } \\
\text { доб- } \\
\text { рий }\end{array}$ \\
\hline $\begin{array}{l}\text { Лідери громадської } \\
\text { думки та представники } \\
\text { органів місцевого са- } \\
\text { моврядування }\end{array}$ & 3,3 & 26,7 & 41,4 & 27,3 & 1,3 \\
\hline $\begin{array}{l}\text { Фахівці лісового гос- } \\
\text { подарства }\end{array}$ & 8,7 & 4,7 & 33,3 & 46,0 & 7,3 \\
\hline $\begin{array}{l}\text { Підприємці (малий біз- } \\
\text { нес) }\end{array}$ & 8,0 & 14,0 & 48,0 & 23,3 & 6,7 \\
\hline $\begin{array}{l}\text { Загалом мешканці гро- } \\
\text { мад }\end{array}$ & 6,7 & 15,1 & 40,9 & 32,2 & 5,1 \\
\hline
\end{tabular}

Значна частина мешканців гірських регіонів достатньо добре обізнана з екологічними проблемами своєї місцевості - 56,7 \% респондентів, натомість обізнаність 3 чинним законодавством у сфері ведення лісового господарства в Україні та з правовим регулюванням у цій же сфері у країнах Свропейського Союзу є меншою, відповідно 50,0 та 12,0 \% опитаних респондентів.

Незважаючи на середній рівень обізнаності мешканців громад із чинним законодавством країни, про можливості впливати на прийняття рішень у сфері лісового господарства достатньо добре знають тільки 44,0 \% респондентів. Натомість $54 \%$ місцевих жителів стверджують, що не мають жодного впливу на вирішення проблем, які стосуються використання лісових ресурсів у їхній місцевості.

Найвагомішими загрозами ("становить загрозу" та "становить значну загрозу") для стану лісових екосистем у Карпатському регіоні України, на думку представників малого бізнесу, є (табл. 2):

- недосконала законодавча база (72,0 \% респондентів);

- корупційні схеми заготівлі деревини $(65,3 \%)$;

- самовільне вирубування лісів місцевими жителями (64 \%);

- низька екологічна культура мешканців (по 64,0 \% респондентів).

Натомість відвідування лісу місцевими мешканцями у рекреаційних цілях та для збирання ягід, грибів і лікарської сировини "не становить загрози" та "радше не становить загрози" лісовим екосистемам - 71,3\% опитаних респондентів.

Табл. 2. Вагомі загрози для стану лісів у Карпатському регіоні країни, \% опитаних респондентів / Significant threats to the state of forests in the Carpathian region of the country, $\%$ of respondents

\begin{tabular}{|l|c|c|c|}
\hline \multicolumn{1}{|c|}{ Загроза для стану лісів } & $\begin{array}{c}\text { Важко } \\
\text { відповісти }\end{array}$ & $\begin{array}{c}\text { Не становить загрози та радше не } \\
\text { становить загрози, ніж є загрозою }\end{array}$ & $\begin{array}{c}\text { Становить загрозу та } \\
\text { становить значну загрозу }\end{array}$ \\
\hline Відвідування лісу рекреантами & 2,0 & 71,3 & 26,7 \\
\hline $\begin{array}{l}\text { Нераціональна діяльність лісогосподарських під- } \\
\text { приємств }\end{array}$ & 2,7 & 58,0 & 59,3 \\
\hline $\begin{array}{l}\text { Зловживання під час експлуатації лісових ресурсів 3 } \\
\text { боку органів місцевої влади }\end{array}$ & 0,7 & 46,7 & 57,6 \\
\hline Погана охорона лісу & 4,0 & 38,7 & 61,3 \\
\hline $\begin{array}{l}\text { Зловживання під час експлуатації лісових ресурсів 3 } \\
\text { боку бізнесових структур }\end{array}$ & 2,0 & 36,7 & 62,0 \\
\hline Передача лісу в оренду тимчасовим лісокористувачам & 5,3 & 30,7 & 64,0 \\
\hline Низька екологічна культура мешканців & 1,3 & 34,7 & 64,0 \\
\hline Самовільне вирубування лісів місцевими жителями & 0,7 & 35,3 & 65,3 \\
\hline Корупційні схеми заготівлі деревини & 2,7 & 32,0 & 72,0 \\
\hline Недосконала законодавча база & 3,3 & 24,7 & \\
\hline
\end{tabular}

Загалом наявна практика доступу малого бізнесу до лісових ресурсів "влаштовує" тільки 24,7 \% мешканців гірських громад. "Частково влаштовує" - 48,0 \%, а "не влаштовує" - 27,3 \% місцевих жителів.

Щодо законного доступу до отримання деревини для ведення малого бізнесу то, на думку більшості мешканців гірських регіонів, "законно отримати деревину складно, але можливо" - 54,7\% респондентів. 34,7\% місцевих жителів вважають, що "з цим не виникає жодних проблем", а 10,6 \% зазначають, що "законно отримати деревину для ведення бізнесу є практично неможливо".

Найбільш вживаними способами отримання деревини для ведення малого бізнесу, на думку місцевих підприємців, є:

- самостійна законна заготівля деревини відповідно до чинного законодавства - 43,3 \% респондентів;

- купівля деревини для ведення бізнесу в посередницьких фірмах та в інших підприємців - 26,7\%;

- купівля деревини на аукціонах - 16,0 \% респондентів.

Однак частина представників малого бізнесу вдається і до незаконних шляхів отримання деревини - 26,7 \% купують деревину в місцевих мешканців, що заготовляють іiі самовільно, а 13,3 \% купують деревину для ведення бізнесу у нелегальних лісозаготівельників.
Основними чинниками, що найбільше спонукають до використання деревини незаконного походження в малому бізнесі, мешканці гірських громад насамперед вважають (табл. 3):

- різницю в цінах на деревину законного та незаконного походження - 58,7 \% респондентів;

- достатньо простий спосіб отримання деревини - 37,3 \%;

- наявність тіньового сектору в економіці 26,0 \%;

- відсутність ефективних штрафних санкцій - 18,7 \% респондентів.

Основними заходами, які сприяли б усуненню використання деревини незаконного походження у підприємницькій діяльності представники малого бізнесу вважають (табл. 4):

- припинення нелегального експорту переробленої деревини $-64,7 \%$ респондентів;

- посилення митного контролю - 61,3\%;

- покращення роботи правоохоронних органів - 60,0\%;

- сертифікація походження деревини - 53,3\% респондентів.

Передача ділянок лісу в постійне користування гірських громаді, в приватну власність чи в оренду підприємцям, на думку представників малого бізнесу, не значно сприятимуть усуненню використання деревини незаконного походження у своїй підприємницькій діяльності. 
Табл. 3. Чинники, що спонукають до використання деревини незаконного походження в малому бізнесі / Factors encouraging the use of illegal timber in small-scale business

\begin{tabular}{|l|c|c|c|}
\hline \multicolumn{1}{|c|}{ Чинник } & $\begin{array}{c}\text { Важко від- } \\
\text { повісти }\end{array}$ & $\begin{array}{c}\text { Не спонукають до } \\
\text { використання }\end{array}$ & $\begin{array}{c}\text { Спонукають до } \\
\text { використання }\end{array}$ \\
\hline Значний попит на деревину & 3,3 & 84,0 & 12,7 \\
\hline Недостатній контроль за здійсненням рубань на місцях & 3,3 & 83,4 & 13,3 \\
\hline Значна кількість пропозицій деревини незаконного походження & 3,3 & 79,3 & 17,3 \\
\hline Відсутність ефективних штрафних санкцій & 3,3 & 77,3 & 18,7 \\
\hline Наянність тіньового сектору в економіці & 3,3 & 70,7 & 26,0 \\
\hline Достатньо простий спосіб отримання деревини & 3,3 & 53,3 & 37,3 \\
\hline Різниця в цінах на деревину законного та незаконного походження & 4,7 & 36,7 & 58,6 \\
\hline
\end{tabular}

Табл. 4. Заходи, що сприяють усуненню використання деревини незаконного походження в малому бізнесі / Measures to eliminate the use of illegal timber in small-scale businesses

\begin{tabular}{|l|c|c|c|}
\hline \multicolumn{1}{|c|}{ Захід } & $\begin{array}{c}\text { Важко } \\
\text { відповісти }\end{array}$ & $\begin{array}{c}\text { Не сприяють } \\
\text { усуненню }\end{array}$ & $\begin{array}{c}\text { Сприяють } \\
\text { усуненню }\end{array}$ \\
\hline Передача ділянок лісу в оренду підприємцям & 28,7 & 42,0 & 29,3 \\
\hline Передача ділянок лісу в приватну власність & 30,7 & 40,0 & 29,3 \\
\hline Передача ділянок лісу в постійне користування місцевій громаді & 22.7 & 39,3 & 38,0 \\
\hline Сертифікація продукції з деревини & 36,7 & 20,0 & 43,3 \\
\hline Підвищення штрафних санкцій & 23,3 & 27,3 & 49,4 \\
\hline Посилення громадського контролю & 24,0 & 24,0 & 52,0 \\
\hline Сертифікація походження деревини & 36,0 & 10,7 & 53.3 \\
\hline Покращення роботи правоохоронних органів & 26,7 & 13,3 & 60,0 \\
\hline Посилення митного контролю & 24,0 & 14,7 & 61,3 \\
\hline Припинення нелегального експорту переробленої деревини & 26,0 & 9,3 & 64,7 \\
\hline
\end{tabular}

Невідкладними заходами, що сприяють забезпеченню прав малого бізнесу на використання деревини та інших лісових ресурсів, $є$ (табл. 5):

- налагодження партнерських стосунків між бізнесменами, громадою та владними структурами - 33,3 \% респондентів;

- забезпечення прозорості механізму прийняття рішень владними структурами $-32,7 \%$;

- відкритість та доступність інформації щодо проблем лісового господарства $-28,7$ \% респондентів.
Проведені дослідження показали, що найважливішим у забезпеченні прозорості/доступності малого бізнесу до деревини та інших лісових ресурсів є потреба зменшення кількості дозвільних процедур і потрібних документів (76,7 \% респондентів), а також зменшення тиску владних і політичних структур на малий бізнес та ведення підприємницької діяльності (74,0% респондентів) (табл. 6).

Табл. 5. Заходи, що сприяють забезпеченню прав малого бізнесу на використання лісових ресурсів / Measures to ensure the rights of small-scale businesses to use forest resources

\begin{tabular}{|l|c|c|c|}
\hline \multicolumn{1}{|c|}{ Захід } & $\begin{array}{c}\text { Важко від- } \\
\text { повісти }\end{array}$ & $\begin{array}{c}\text { Не сприяють за- } \\
\text { безпеченню }\end{array}$ & $\begin{array}{c}\text { Сприяють забез- } \\
\text { печенню }\end{array}$ \\
\hline Проведення аукціонів & 5,3 & 82,0 & 12,7 \\
\hline Підвищення правової обізнаності підприємців & 5,3 & 70,0 & 24,7 \\
\hline $\begin{array}{l}\text { Створення відрегульованого правового механізму участі підприємців у про- } \\
\text { цесах прийняття рішень у сфері лісових відносин }\end{array}$ & 5,3 & 69,4 & 25,3 \\
\hline Відкритість та доступність інформації щодо проблем лісового господарства & 5,3 & 66,0 & 28,7 \\
\hline Забезпечення прозорості механізму прийнятя рішень владними структурами & 5,3 & 62,0 & 32,7 \\
\hline $\begin{array}{l}\text { Налагодження партнерських стосунків між бізнесменами, громадою та влад- } \\
\text { ними структурами }\end{array}$ & 5,3 & 61,3 & 33,3 \\
\hline
\end{tabular}

Табл. 6. Важливість шляхів забезпечення прозорості/доступності малого бізнесу до деревини та інших лісових ресурсів / The importance of ways to ensure the transparency / availability of small-scale businesses to timber and other forest resources

\begin{tabular}{|l|c|c|c|}
\hline \multicolumn{1}{|c|}{ Шляхи забезпечення прозорості/доступності } & $\begin{array}{c}\text { Важко відпо- } \\
\text { вісти }\end{array}$ & $\begin{array}{c}\text { 3овсім не важливо та } \\
\text { не дуже важливо }\end{array}$ & $\begin{array}{c}\text { Важливо та надзви- } \\
\text { чайно важливо }\end{array}$ \\
\hline $\begin{array}{l}\text { Покращення інформаційного забезпечення представників малого } \\
\text { бізнесу, органів влади та дозвільних органів для роз'яснення меха- } \\
\text { нізмів прозорого доступу до деревини }\end{array}$ & 20,0 & 28,7 & 51,3 \\
\hline $\begin{array}{l}\text { Удосконалення правових норм, що перешкоджають легальному } \\
\text { використанню лісових ресурсів }\end{array}$ & 12,0 & 16,7 & 71,3 \\
\hline Зменшення тиску владних і політичних структур & 12,0 & 14,0 & 74,0 \\
\hline Зменшення кількості дозвільних процедур і документів & 12,0 & 10.0 & 76,7 \\
\hline
\end{tabular}

\section{Висновки / Conclusions}

Більшість мешканців громад Карпатського регіону України загальний стан лісових насаджень у їхній місцевості оцінює як "радше поганий, ніж добрий" (40,9 \% опитаних респондентів).

Переважна частина мешканців гірських регіонів достатньо добре знає про основні екологічні проблеми своєї місцевості (56,7 \% респондентів), досить обізнана із чинним законодавством у сфері ведення лісового господарства в Україні та практично не ознайомлена із правовим регулюванням у цій самій сфері у країнах Європейського Союзу.

Вагомими загрозами для стану лісових екосистем в Карпатах, на думку представників малого бізнесу, є: недосконала законодавча база, корупційні схеми заготівлі деревини, самовільне вирубування лісів місцевими жителями та низька екологічна культура мешканців. 
Наявна практика доступу малого бізнесу до лісових ресурсів "не влаштовує" 27,3\% місцевих жителів, а "частково влаштовує" 48,0 \% мешканців гірських громад. Найчастішими способами отримання деревини для ведення малого бізнесу є самостійна законна заготівля деревини відповідно до чинного законодавства (43,3 \%) та купівля деревини для ведення бізнесу в посередницьких фірмах і в інших підприємців (26,7 \% респондентів).

Найвагомішими чинниками, що спонукають до використання деревини незаконного походження в малому бізнесі, місцеві мешканці громад вважають різницю в цінах на деревину законного та незаконного походження $(58,7 \%)$, достатньо простий спосіб отримання деревини $(37,3 \%)$ та наявність тіньового сектору в економіці (26,0 \% респондентів).

Вагомими заходами, що сприяють усуненню використання деревини незаконного походження у підприємницькій діяльності є припинення нелегального експорту переробленої деревини (64,7 \%), посилення митного контролю $(61,3 \%)$, покращення роботи правоохоронних органів $(60,0 \%)$ та сертифікація походження деревини (53,3 \% респондентів).

Невідкладними заходами, що сприяють забезпеченню прав малого бізнесу на використання деревини та інших лісових ресурсів, на думку мешканців місцевих громад, є налагодження партнерських стосунків між бізнесменами, громадою та владними структурами, а також забезпечення прозорості механізму прийняття рішень владними структурами.

Найважливішим у забезпеченні доступності малого бізнесу до деревини та інших лісових ресурсів $\epsilon$ потреба зменшення кількості дозвільних процедур і потрібних документів та зменшення тиску владних і політичних структур на малий бізнес і ведення підприємницької діяльності.

Забезпечення доступу малого бізнесу до деревини та інших лісових ресурсів, а також прозорості ведення підприємницької діяльності мешканцями громад лісистих регіонів, сприятиме покращенню рівня добробуту місцевих жителів та поступальному сталому розвитку територіальних громад у Карпатському регіоні України.

\section{References}

1. Biuiul, A., \& Efel, P. (2002). SPSS: Iskusstvo obrabotki informatcii. Analiz statisticheskikh dannykh $i$ vosstanovlenie skrytykh zakonomernostei: per. s nem. SPb.: DiaSoftluP, 460 p. [In Russian].
2. Cherniavskyi, M. V., Solovii, I. P., Henyk, Ya. V., Kaspruk, O. I., Henyk, O. V., et al. (2011). Problemy dostupu mistsevoho naselennia do lisovykh resursiv ta nezakonni rubky v lisakh Karpat ta Zakhidnoho Polissia. Monohrafiia. Lviv: Zelenyi Khrest, LihaPres, 256 p. [In Ukrainian].

3. Deineka, A. M. (2009). Lisove hospodarstvo: ekoloho-ekonomichni zasady rozvytku. Monohrafiia. Kyiv: Znannia, 350 p. [In Ukrainian].

4. Hensiruk, S. A. (1992). Lisy Ukrainy. Kyiv: Naukova dumka, 408 p. [In Ukrainian].

5. Henyk, Ya. V., Solovii, I. P., Cherniavskyi, M. V., Henyk, O. V., et al. (2018). Osnovni prychyny pravoporushen v lisakh Ukrainskykh Karpat ta zakhody iz yikh zapobihannia. Osnovni problemy y tendentsii podalshoho rozvytku lisovoho hospodarstva $v$ Ukrainskykh Karpatakh: zb. mater. mizhn. nauk.-prakt. konf. Ivano-Frankivsk: "NAIR", 276-282. [In Ukrainian].

6. Holubets, M. A. (2000). Ekosystemolohiia. Lviv: Polli, 316 p. [In Ukrainian].

7. Holubets, M. A. (2010). Seredovyshcheznavstvo (invaironmentolohiia). Lviv: Manuskrypt, 176 p. [In Ukrainian].

8. Kalutskyi, I. F. (1998). Vitrovaly na pivnichno-skhidnomu makroskhyli v Ukrainskykh Karpatakh. Monohrafiia. Lviv: Manuskrypt, 208 p. [In Ukrainian].

9. Krynytskyi, H. T., \& Tretiak, P. R. (2003). Stan lisiv Ukrainskykh Karpat, ekolohichni problemy ta perspektyvy. Zbirnyk naukovykh prats NTSh, T. KhI, 54-65. Lviv. [In Ukrainian].

10. Melnykovych, M. P. (2018). Indykatory otsiniuvannia sotsio-ekoloho-ekonomichnoho rozvytku Karpatskoho rehionu. Zbirnyk naukovykh prats NUVHP, 2(82), 335-354. Rivne: NUVHP. [In Ukrainian].

11. Paniotto, V. I. (1986). Kachestvo sotciologicheskoi informatcii. Kiiv: Naukova dumka, 207 p. [In Russian].

12. Parpan, V. I., \& Parpan, T. V. (2008). Osnovni pryntsypy suchasnoi paradyhmy hirskoho lisoznavstva ta lisivnytstva Ukrainskykh Karpat. Zbirnyk naukovykh prats. Lisivnytstvo i ahrolisomelioratsiia, 114, 7-12. Kharkiv: UkrNDILHA. [In Ukrainian].

13. Solodkyi, V. D. (2012). Lisy Bukovyny: Bukovynski Karpaty ta Peredkarpattia. Monohrafiia. Chernivtsi: Zelena Bukovyna, 320 p. [In Ukrainian].

14. Solovii, I. P. (2010). Polityka staloho rozvytku lisovoho sektora ekonomiky: paradyhma ta instrumenty. Monohrafiia. Lviv: LihaPres, 368 p. [In Ukrainian].

15. Stoiko, M. S. (2009). Dubovi lisy Ukrainskykh Karpat: ekolohichni osoblyvosti, vidtvorennia, okhorona rozvytku. Monohrafiia. Lviv: Merkator, 220 p. [In Ukrainian].

16. Syniakevych, I. M., Solovii, I. P., Vrublevska, O. V., Deineka, A. M., Polovskyi, A. M., et al. (2008). Lisova polityka: teoriia $i$ praktyka. Monohrafiia. Lviv: LA "Piramida", 612 p. [In Ukrainian].

O. V. Henyk', M. P. Melnykovych', Ya. V. Henyk ${ }^{1}$

${ }^{I}$ Ukrainian National Forestry University, Lviv, Ukraine ${ }^{2}$ Swiss Federal Institute for Forest, Snow and Landscape Research (WSL), Switzerland

\section{AVAILABILITY OF FOREST RESOURCES TO SMALL-SCALE BUSINESS AND PREVENTION OF THE USE OF ILLEGAL TIMBER IN THE CARPATHIAN REGION OF UKRAINE}

Socio-economic development of territorial communities in the Carpathian region of Ukraine largely characterizes the level of development of entrepreneurship and small business, which is associated with forest ecosystems and forest resources. Given the significant importance of forest ecosystems for the inhabitants of mountain communities, the issues of access of small businesses to forest resources and prevention of the use of illegal timber in business activities are extremely important. Therefore, the purpose of the research is to reveal opportunities for obtaining timber for business activities and to identify priority measures to promote the rights of small-scale businesses to use forest resources. The research was performed by the method of standard face-to-face survey of the representatives of local communities of Khust District of Zakarpattia Region, Kosiv District and Yaremche Town Council of IvanoFrankivsk Region, and also Skole and Starosambir Districts of Lviv Region. The research areas are characterized by significant forest cover, and the forest industry plays an important role in the regions economy. The experts were the representatives of local governments, small businesses and forestry specialists (a total of 450 respondents), who are quite well acquainted with the state of affairs in the forest sector of the region and are leaders of public opinion. The analysis of the main threats to the forest ecosystems of the district showed that the most important of them are as follows: imperfect legal framework $(72.0 \%)$, corrupt timber harvesting sche- 
mes $(65.3 \%)$; unauthorized deforestation by locals $(64.0 \%)$, and low ecological culture of residents $(64.0 \%$ of respondents). The main factors that mostly motivate the use of illegal timber in small-scale business are as follows: the difference in prices for timber of legal and illegal origin (58.6\%), a fairly simple way to obtain timber $(37.3 \%)$, the presence of the shadow sector in the economy ( $26.0 \%$ ) and the lack of effective penalties (18.7\% of respondents). Priority measures to eliminate the use of illegal timber in business activities are found to be the following: cessation of illegal export of processed wood $(64.7 \%)$, strengthening customs control $(61.3 \%)$, improving the work of law enforcement agencies $(60.0 \%)$, and certification of timber origin (53.3\% of respondents). The main measures to ensure the rights of small-scale businesses to use wood and other forest resources are as follows: establishing partnerships between businessmen, the community and the authorities $(33.3 \%)$, ensuring transparency of the decision-making mechanism of the authorities $(32.7 \%)$, and openness and availability of information on forestry problems $(27.7 \%$ of respondents). The most important thing in ensuring the availability of small-scale businesses to forest resources is to reduce the number of permitting procedures and documents and also reduce the pressure of government and political structures on small-scale business and doing business. Ensuring access of small-scale businesses to timber and other forest resources, as well as transparency of business activities by residents of forest communities, will help improve the welfare of local residents and sustainable development of local communities in the Carpathian region of Ukraine.

Keywords: forest ecosystems; access to forest resources; illegal timber; business activity; inhabitants of mountain communities. 